\title{
RANCANG BANGUN BATTERY CHARGE CONTROLLER DUAL SUMBER SUPLAI BEBAN DENGAN PLTS DAN PLN BERBASIS MIKROKONTROLER
}

\author{
Giri Woryanto, Dikpride Despa, Endah Komalasari, Noer Soedjarwanto \\ Jurusan Teknik Elektro Universitas Lampung \\ Jl. Prof. Sumantri Brojonegoro No. 1 Bandar Lampung 35145 \\ giriworyanto@gmail.com
}

\begin{abstract}
Abstrak
Penelitian yang dilakukan bertujuan untuk memasang suatu pembangkit listrik sebagai pensuplai utama fingerprint berupa PLTS ( Pembangkit Listrik Tenaga Surya ) dengan kendali dual sumber suplai fingerprint, dan sumber PLN ( Perusahaan Listrik Negara ) sebagai cadangan. Sistem yang dibuat menggunakan dua buah baterai untuk menyimpan energi dari PLTS. Mikrokontroler digunakan untuk mengendalikan pergantian antara kedua baterai dalam pengecasan dan suplai fingerprint, serta pemindahan sumber suplai ke PLN saat semua baterai dalam kondisi kosong.
\end{abstract}

Kata Kunci: Dual Sumber, Mikrokontroler, Fingerprint.

\begin{abstract}
The purpose of this researh is to put an solar power as the main supplier of fingerprint machine that have dual source fingerprint supply power has PLN as a backup source. The system has made by using two batteries to store energy from solar. The microcontroller is used to control a switch of two batteries at charging and supply fingerprint, then to removal the source to PLN when all batteries at the discharged condition.
\end{abstract}

Keywords: Dual Source, Microcontroller, Fingerprint.

\section{PENDAHULUAN}

Sistem absensi kehadiran digital berupa fingerprint diterapkan di Universitas Lampung untuk memudahkan dalam melakukan absensi dan meningkatkan produktifitas karyawan yang berawal dari kedisiplinan atas kehadiran karyawan di tempat kerja. Tetapi ketika terjadi pemadaman listrik, fingerprint tidak dapat digunakan karena sumber listrik PLN yang terputus sehingga fingerprint tidak dapat beroperasi. Hal ini mendorong dilakukannya sebuah penelitian untuk dapat memasang pembangkit listrik yang hanya berfungsi sebagai pensuplai fingerprint berupa PLTS.
PLTS memiliki kekurangan karena sangat bergantung pada cuaca dalam hal pengisian baterai. Untuk menjaga kontinuitas suplai daya ke fingerprint ketika baterai kosong dan terjadi masalah pada PLTS dalam proses pengisian baterai. Charge controller sebagai kendali utama pengisian baterai akan memindahkan suplai daya dari sumber energi PLTS ke PLN untuk pengoperasian fingerprint.

Sebenarnya, charge controller di pasaran sudah memiliki fitur dalam kendali pengisian baterai, tetapi masih memiliki kekurangan dengan tidak terdapatnya sistem dual sumber energi suplai beban dan sistem switching otomatis ke beban berdasarkan waktu pemakaiannya. Hal tersebut 
membentuk sebuah gagasan untuk membuat battery charge controller dengan dual sumber energi suplai beban dan switching otomatis berdasarkan jam pemakaian beban berbasis mikrokontroler untuk menjaga agar fingerprint dapat selalu beroperasi bila terjadi masalah pada PLTS dan sebagai langkah penghematan baterai.

\section{TINJAUAN PUSTAKA}

\subsection{Sistem Sel Surya}

Sel surya adalah suatu teknologi yang dapat mengubah energi sinar matahari secara langsung menjadi energi listrik. Sel surya ini banyak digunakan untuk penyediaan tenaga lsitrik bagi penerangan, pompa air, telekomunikasi dan lain sebagainya. Pemanfaatan sistem sel surya sebagai pembangkit tenaga listrik tersebut telah banyak diterapkan, baik yang menghasilkan daya rendah maupun yang berdaya tinggi. Sistem sel surya bila tinjau dari daya keluarannya dapat dibagi menjadi:

\section{Sistem yang berdiri sendiri}

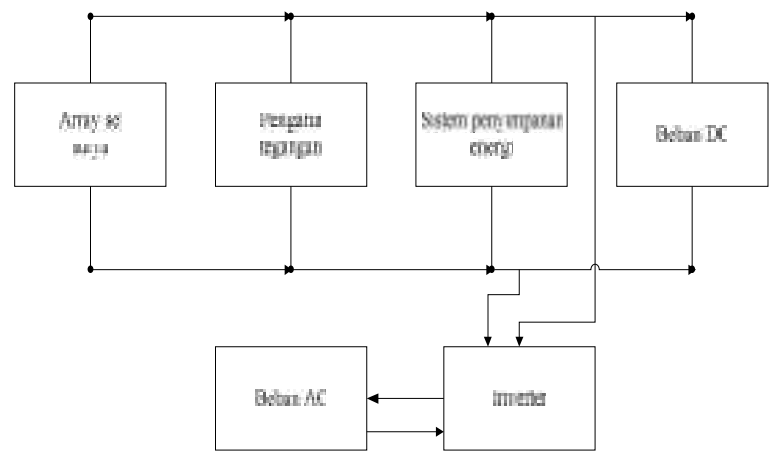

Gambar 2.1 Skema sederhana komponen suatu sel surya yang berdiri sendiri.[3]

Gambar 2.1 menunjukkan desain pembangkit listrik sel sel surya yang berdiri sendiri tidak memperhatikan sumber energi luar selain energi radiasi matahari. Sistem yang berdiri sendiri dapat mensuplai beban DC maupun beban AC dengan menggunakan inverter.

2. Sistem yang terinterkoneksi dengan jaringan pengguna
Gambar 2.2 menunjukkan sistem pembangkit listrik tenaga sel surya yang berinterkoneksi dengan jaringan pengguna, kelebihan beban yang tidak dapat disuplai oleh pembangkit akan disuplai oleh jaringan. Sebaliknya, jika kondisi cuaca sangat baik serta permintaan beban berkurang, maka kelebihan energi listrik yang dihasilkan oleh pembangkit akan ditampung oleh jaringan pengguna.

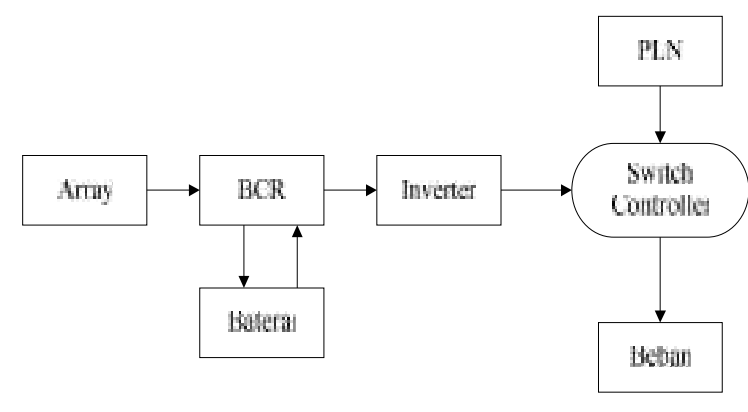

Gambar 2.2 Sistem sel surya terinterkoneksi dengan jaringan pengguna.[3]

\subsection{Real Time Clock}

Real Time Clock ( RTC ) berhubungan dengan waktu, mulai dari detik, menit, jam, hari, tanggal, bulan dan tahun. Tetapi IC RTC ini juga bisa dipakai untuk menyimpan data di dalam internal RAM RTC, di mana data tersebut tidak bisa hilang meskipun supply diputus, hal ini karena di dalam IC RTC tersebut ada baterai yang selalu hidup untuk menjalankan clock-nya, jadi waktu (clock) tetap berjalan meskipun supply dimatikan. IC RTC ini masih mempunyai kelebihan yaitu bisa dipakai sebagai timer atau alarm. Untuk hitungan detik, menit, jam, hari, tanggal, bulan dan tahun dengan tahun kabisat yang valid sampai 2100. Mode yang dipilih bisa 24 jam atau dengan AM dan PM pada mode 12 jam.[2]

\subsection{Sistem Hybrid}

Sistem hybrid PLTS dengan listrik PLN (grid connected) atau sumber pembangkit listrik yang lain dapat diklasifikasikan menjadi dua jenis, yaitu tanpa baterai dan yang menggunakan baterai.[4] Sistem hibrid PLTS dengan listrik PLN dapat diterapkan pada rumah diperkotaan, serta menganalisis faktor yang mempengaruhi besarnya energi listrik yang dihasilkan sel surya berkaitan dengan waktu kerja sistem PLTS. PLTS akan 
memasok energi listrik sekitar $30 \%$ dari beban keseluruhan peralatan listrik rumah tangga, sedangkan 70\% listrik sisanya dari PLN.[4]

Hibridasi antara PLTS dengan listrik PLN bertujuan untuk mendapatkan kekontinuan pasokan (supply) listrik ke beban. Pada sistem hibrid PLTS dengan PLN yang akan dirancang, terdiri dari array fotovoltaik, regulator (charge controller), baterai, dan inverter. Listrik arus searah (DC) dari modul fotovoltaik, akan diubah menjadi arus bolakbalik (AC) melalui inverter.

\section{METODE PENELITIAN}

\subsection{Metode Penelitian}

Metode penelitian yang digunakan dalam penelitian adalah menerapkan mikrokontroler sebagai pengendali proses pengisian baterai dan switching otomatis fingerprint. Mikrokontroler adalah sebuah sistem komputer fungsional dalam sebuah chip. Di dalamnya terkandung sebuah inti prosesor, memori (sejumlah kecil RAM, memori program, atau keduanya), dan perlengkapan input output. Dengan kata lain, mikrokontroler adalah suatu alat elektronika digital yang mempunyai masukan dan keluaran serta kendali dengan program yang bisa ditulis dan dihapus dengan cara khusus, cara kerja mikrokontroler sebenarnya membaca dan menulis data. Beberapa tahun terakhir, mikrokontroler sangat banyak digunakan terutama dalam pengontrolan robot.[1]

Proses kerja dari mikrokontroler pada perancangan alat ini dimulai dengan melihat level tegangan baterai dalam kondisi seperti apa, bila sudah pada level pengisian maka mikrokontroler akan membaca terlebih dahulu besar tegangan yang dihasilkan oleh PLTS. Pengisian baterai akan dilakukan oleh PLTS bila tegangan yang dihasilkannya sesuai dengan setting dari alat, bila tidak maka listrik dari PLN yang akan digunakan untuk mengisi baterai. Mikrokontroler akan terus mendeteksi level tegangan baterai saat pengisian, jika baterai sudah penuh maka proses pengisian akan dihentikan dengan memutus jalur dari sumber pengisian ke baterai. Mikrokontroler juga berfungsi sebagai pengendali untuk menyalakan atau mematikan fingerprint secara otomatis dengan input dari IC RTC. Jika waktu menunjukkan antara pukul 07.00 - 17.00 WIB maka mikrokontroler akan menyambungkan suplai tegangan ke fingerprint untuk beroperasi, namun fingerprint akan berada pada posisi off bila waktu tidak sesuai dengan pengaturan untuk fingerprint on.

\subsection{Blok Diagram Sistem}

Perancangan blok diagram dilakukan dengan tujuan untuk mempermudah realisasi sistem yang akan dibuat.

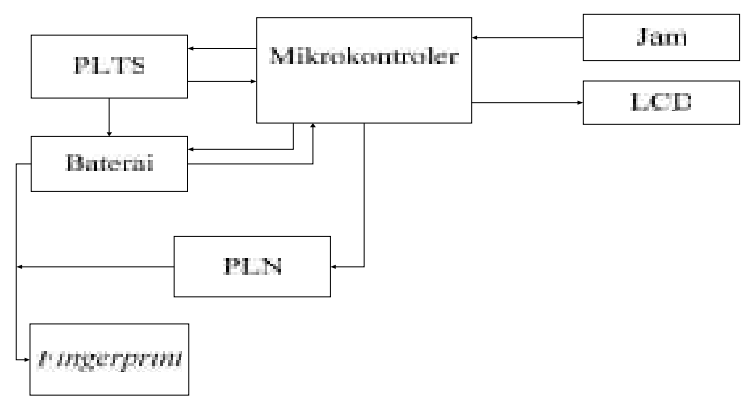

Gambar 3.1 Diagram perancangan Battery Charge Controller

Dari gambar 3.1 dapat dilihat bahwa mikrokontroler sebagai pusat pengandali dari keseluruhan alat. Mikrokontroler mengendalikan pengaturan sumber suplai fingerprint antara PLTS dan PLN. Mikrokontroler juga mengatur waktu fingerprint untuk menyala dan mati berdasarkan masukan dari jam yang berupa rangkaian real time clock. LCD digunakan untuk menampilkan tegangan dari PLTS, sumber suplai fingerprint, hari, jam, serta baterai yang sedang digunakani untuk suplai fingerprint.

\subsubsection{Diagram alir prinsip kerja alat}

Dari gambar 3.2 menjelaskan tentang prinsip kerja dari proses pengisian baterai. Charge controller berperan penting dalam proses pengisian baterai. Pertama Mikrokontroler melihat besar tegangan baterai 1 dan 2 mana yang sudah pada level tegangan untuk pengisian, bila ada yang kosong maka akan dilakukan pengisian. Saat PLTS bisa menghasilkan tegangan yang sesuai dengan pengaturan untuk pengisian baterai dari alat, maka proses pengisian baterai akan berlangsung dengan sumber energi dari PLTS, dan kemudian baterai 
yang tidak dicas digunakan sebagai sumber energi untuk pengoperasian fingerprint. Batas tegangan PLTS dapat melakukan pengecasan diatur harus lebih besar dari 12,30 volt baru bisa untuk mengecas karena baterai akan mulai dicas saat tegangannya mencapai 12,30 volt, proses pengisian bisa berjalan bila tegangan sumber pengisian lebih besar dari tegangan baterai.

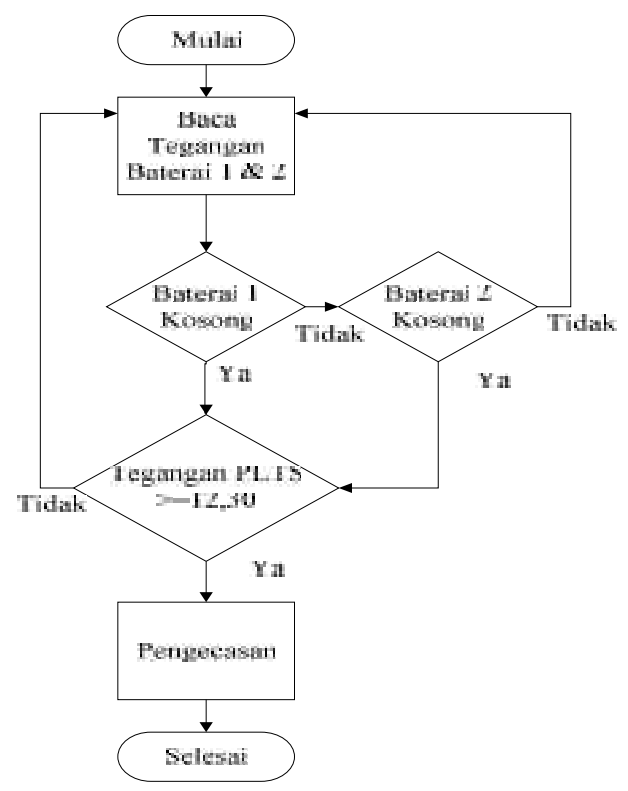

Gambar 3.2 Diagram alir prinsip kerja pengisian

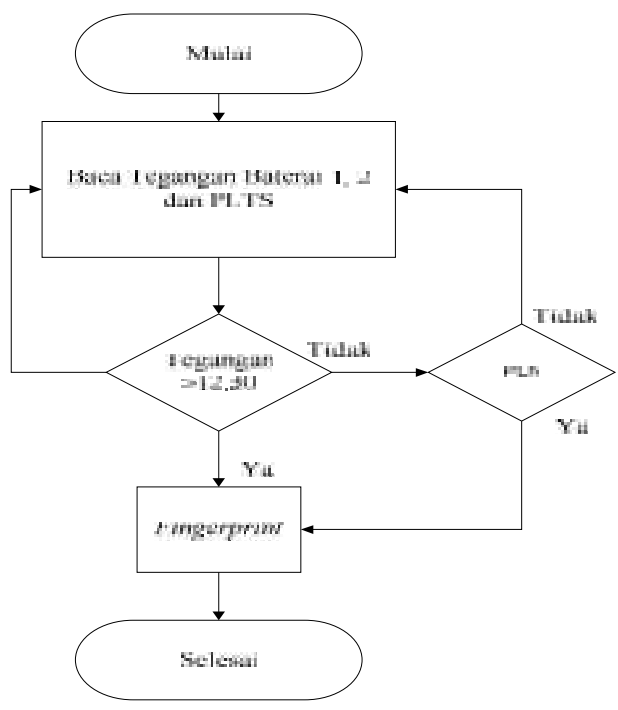

Gambar 3.3 Diagram alir kerja suplai beban
Battery Charge Controller ini menerapkan sistem dual energi dalam suplai beban, dengan sumber energi cadangan suplai beban berasal dari listrik PLN. Sistem dual energi dibuat sebagai langkah antisipasi dalam menjaga kehandalan pengoperasian fingerprint, karena bila suatu ketika terjadi masalah yang menyebabkan PLTS tidak dapat melakukan pengisian baterai serta kedua baterai dalam kondisi kosong diharapkan sistem ini dapat bekerja sehingga listrik dari PLN dapat menyuplai beban, dapat dilihat dari gambar 3.3.

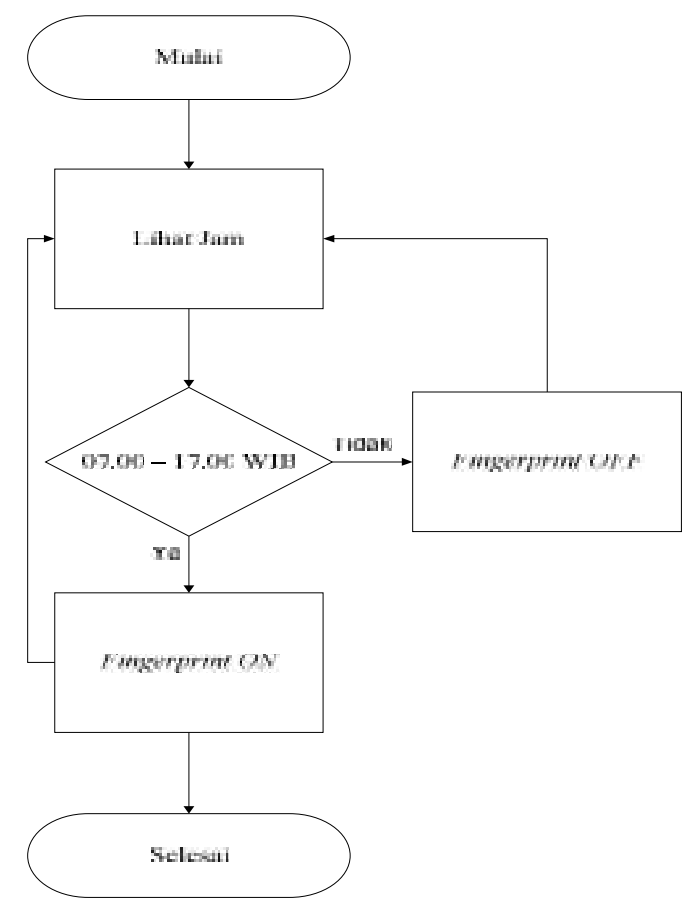

Gambar 3.4 Diagram alir kerja switching otomatis

Dari gambar 3.4 dapat dilihat tentang kerja sistem switching otomatis pengoperasian fingerprint berdasarkan waktu pemakaiannya. Pertama Mikrokontroler akan menerima masukan dari pukul berapakah saat itu, bila waktu menunjukkan pukul 07.00 - 17.00 WIB maka fingerprint akan on, namun bila waktu menunjukkan selain pada pengaturan maka fingerprint akan berada pada posisi off.

Dalam alat ini terdapat 8 buah relay, masingmasing relay memiliki fungsi yang berbeda-beda. Fungsi dari masing-masing relay dapat dilihat dari gambar 3.5 Relay 1 berfungsi untuk memutus dan menyambung antara PLTS dan baterai. Relay 2 dan 3 berfungsi untuk membedakan baterai 1 atau 2 
yang akan dicas oleh PLTS. Relay 4 dan 5 untuk membedakan baterai mana yang akan digunakan sebagai suplai fingerprint. Relay 6 dan 7 untuk membedakan sumber mana yang akan digunakan sebagai suplai fingerprint, apakah dari baterai atau dari PLN. Dan relay 8 sebagai pemutus suplai ke fingerprint, dapat dilihat dari gambar 3.5.

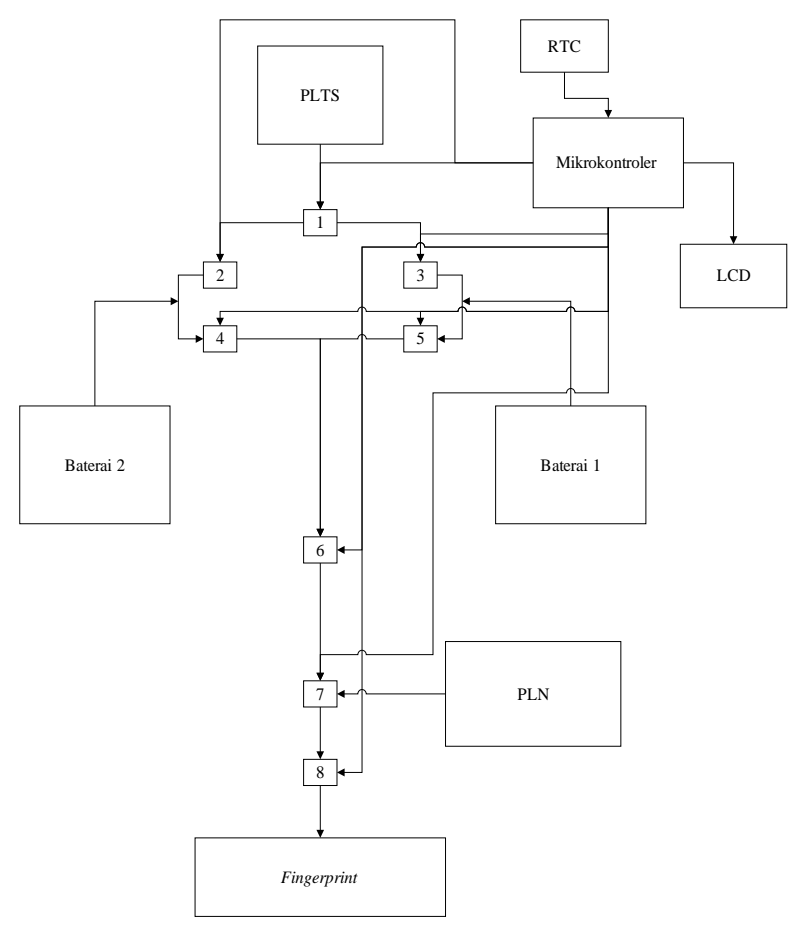

Gambar 3.5 Jalur Relay

\section{HASIL DAN PEMBAHASAN}

\subsection{Spesifikasi Perangkat Keras}

Nama

: Battery Charge Controller

Dual Sumber Suplai Beban dengan PLTS dan PLN

Berbasis Mikrokontroler.

$\begin{array}{ll}\text { Tegangan } & : 12 \mathrm{~V} \mathrm{DC} \\ \text { Arus } & : 0,137 \mathrm{~A} \\ \text { Sistem Kendali } & : \text { Mikrokontroler } \\ \text { Sofware } & : \text { code VisionAVR } \\ \text { Beban } & : \text { Fingerprint }\end{array}$

\subsubsection{Rangkaian Alat Keseluruhan}

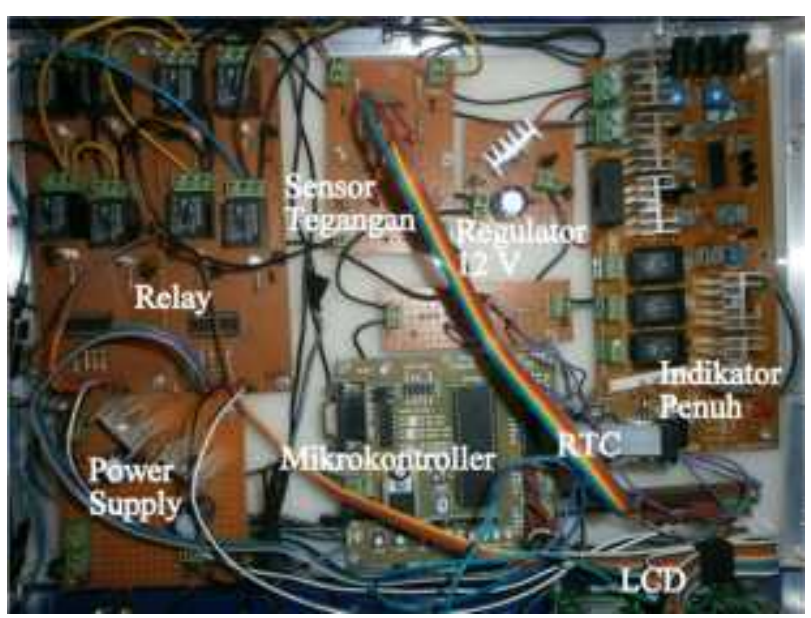

Gambar 4.1 Rangkaian alat keseluruhan

Gambar 4.1 memperlihatkan rangkaian alat secara keseluruhan. Power supply digunakan sebagai tegangan penggerak mikrokontroler dan relay, sumber tegangan dari power supply diperoleh dari baterai 2. Port.A pada rangkaian minimum mikrokontroler mendapat masukan besar tegangan dari baterai 1, baterai 2, PLTS, dan PLN. Port.B digunakan sebagai masukan dari IC yang digunakan untuk real time clock. Port.C sebagai keluaran ke LCD untuk menampilkan waktu, besar tegangan PLTS, juga sebagai indikator baterai berapa yang dipakai untuk suplai fingerprint. Port.D sebagai keluaran untuk driver relay, relay yang digunakan berjumlah 8 buah. Kerja dari alat ini dimulai dengan mendeteksi tegangan pada baterai 1, baterai 2, PLTS dan PLN. Baterai 1 akan digunakan sebagai suplai fingerprint ketika tegangan baterai 2 dibawah 12,30 volt dan tegangan baterai 1 diatas 12,30 volt, saat baterai 1 digunakan untuk suplai fingerprint maka baterai 2 akan dicas oleh PLTS, proses perpindahan antara baterai $1 \mathrm{ke}$ baterai 2 sebagai suplai akan terjadi bila tegangan baterai 1 dibawah 12,30 volt dan tegangan baterai 2 diatas 12,30 volt. Saat baterai yang dicas sudah penuh maka indikator pada rangkaian berupa LED akan menyala, kemudian mikrokontroler akan merespon hal tersebut dengan mematikan relay 1 yang digunakan sebagai penghubung aantara PLTS daan baterai. PLN sebagai sumber suplai cadangan akan bekerja saat baterai 1 dan baterai 2 dalam keadangan kosong semua serta PLTS tidak dapat menghasilkan tegangan yang cukup untuk pengecasan. RTC pada alat ini digunakan sebagai saklar otomatis untuk mematikan dan 
menghidupkan fingerprint. Pada hari senin-jum'at pukul 07.00-17.00 WIB fingerprint akan hidup, selain pada waktu tersebut maka fingerprint akan mati.

\subsection{Perangkat Lunak}

Pada penelitian ini menggunakan pemrograman bahasa $\mathrm{C}$ dengan software codeVisionAVR untuk memprogram mikrokontroler dan menggunakan software Proteus 7 professional untuk melakukan simulasi alat pada komputer. Pada program codeVisionAVR port A mikrokontroler digunakan untuk membaca tegangan dari baterai 1 , baterai 2, PLTS, dan PLN. Port B sebagai masukan dari rangkaian RTC untuk pegaturan waktu. Port C sebagai keluaran dari mikrokontroler ke LCD, dan port D digunakan sebagai penggerak relay.

Prinsip kerja dari program yang yang pertama adalah membaca jam dan hari pada rangkaian RTC untuk kemudian ditampilkan ke LCD, selanjutnya program akan membaca tegangan dari baterai 1, baterai 2, PLTS, dan PLN. Saat jam menunjukkan pukul 07.00 - 17.00 serta antara hari senin jum'at, port D.7 akan bernilai 0 sehingga relay 8 off dan tegangan dari baterai akan mengalir ke fingerprint, selain hari dan jam yang telah diatur untuk menghidupkan fingerprint maka port D.7 aka bernilai 1 sehingga relay 8 on dan tegangan dari baterai tidak akan mengalir ke fingerprint. Selanjutnya program akan membandingkan tegangan pada baterai 1 dan baterai 2. Baterai 1 akan digunakan sebagai suplai fingerprint ketika tegangan baterai 2 dibawah 12,30 volt dan tegangan baterai 1 diatas 12,30 volt, saat baterai 1 digunakan untuk suplai fingerprint maka baterai 2 akan dicas oleh PLTS, proses perpindahan antara baterai $1 \mathrm{ke}$ baterai 2 sebagai suplai akan terjadi bila tegangan baterai 1 dibawah 12,30 volt dan tegangan baterai 2 diatas 12,30 volt. PLN sebagai sumber suplai cadangan akan bekerja saat baterai 1 dan baterai 2 dalam keadangan kosong semua serta PLTS tidak dapat menghasilkan tegangan yang cukup untuk melakukan pengecasan.

\subsection{Pengujian alat}

\subsubsection{Pengujian rangkaian relay}

Dari gambar 4.2 dapat dilihat ketika baterai 1 sebagai suplai fingerprint dan baterai 2 dicas maka relay 1 on untuk menyalurkan tegangan dari PLTS, relay 2 on untuk menghubungkan PLTS dan baterai 1 , dan relay 5 on untuk menghubungkan baterai 2 dengan fingerprint.

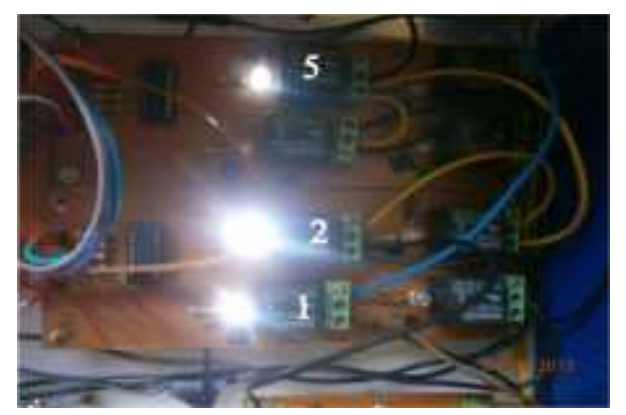

Gambar 4.2 Baterai 1 sebagai suplai fingerprint

Dari gambar 4.3 dapat dilihat ketika baterai 2 sebagai suplai fingerprint dan baterai 1 dicas maka relay 1 on untuk menyalurkan tegangan dari PLTS, relay 3 on untuk menghubungkan PLTS dan baterai 1, dan relay 4 on untuk menghubungkan baterai 2 dengan fingerprint.

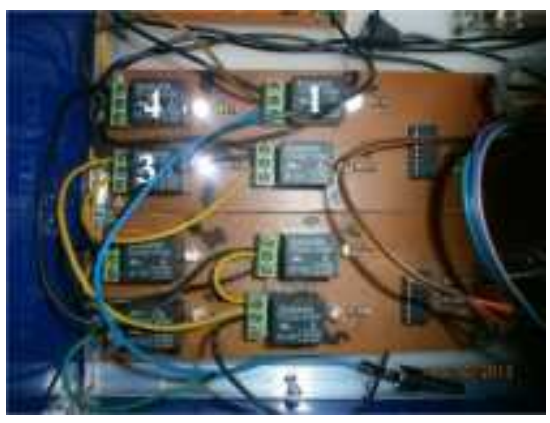

Gambar 4.3 Baterai 2 sebagai suplai fingerprint

Dari gambar 4.4 dapat dilihat saat relay 6 on yang berarti baterai 1 maupun baterai 2 tidak terhubung ke fingerprint, sedangkan relay 7 on yang berarti PLN terhubung sebagai suplai fingerprint untuk mengatasi masalah saat kedua baterai dalam kondisi kosong dan PLTS tidak dapat melakukan pengecasan. 


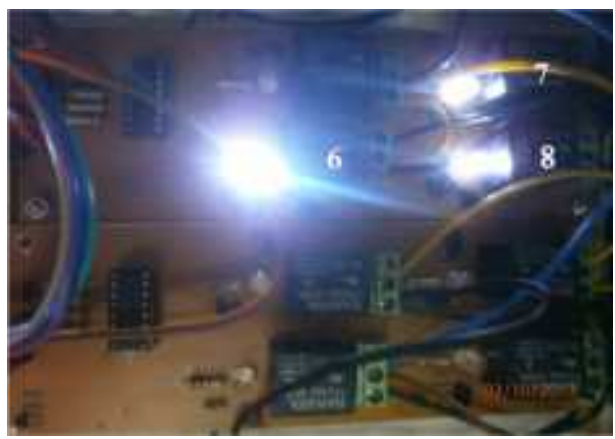

Gambar 4.4 PLN sebagai suplai fingerprint

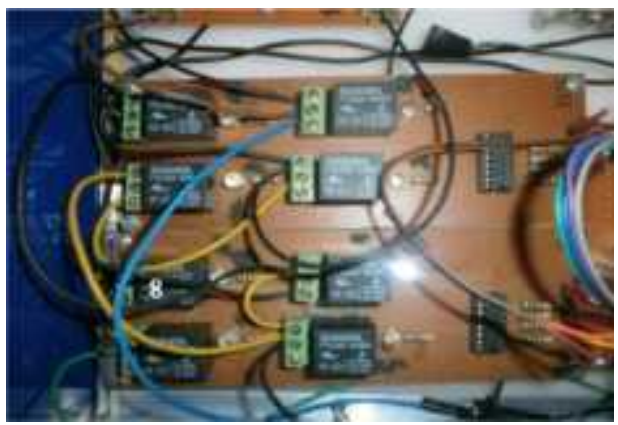

Gambar 4.5 Fingerprint menyala

Gambar 4.5 memperlihatkan kondisi relay ketika fingerprint menyala. Relay 8 yang digunakan sebagai saklar untuk mematikan dan menghidupkan fingerprint dalam kondisi off. Fingerprint akan menyala ketika relay 8 off dan akan mati ketika relay 8 on.

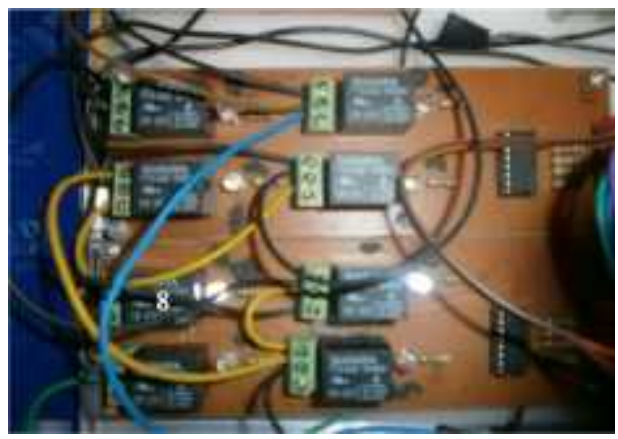

Gambar 4.6 Fingerprint mati

Gambar 4.6 memperlihatkan kondisi relay ketika fingerprint menyala. Relay 8 yang digunakan sebagai saklar untuk mematikan dan menghidupkan fingerprint dalam kondisi on. Fingerprint akan menyala ketika relay 8 off dan akan mati ketika relay 8 on.

\subsubsection{Tampilan LCD}

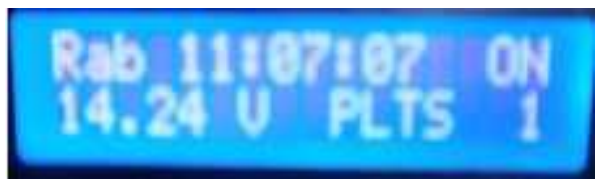

Gambar 4.7 Baterai 1 suplai fingerprint

Dari gambar 4.7 terlihat tampilan dari LCD saat baterai 1 digunakan sebagai suplai pengoperasian fingerprint berupa angka 1 pada ujung bawah sebelah kanan LCD, tertulis juga besar tegangan dari PLTS saat sedang mengecas baterai 1 pada ujung kiri bawah LCD, serta tampilan dari hari dan jam pada baris atas LCD.

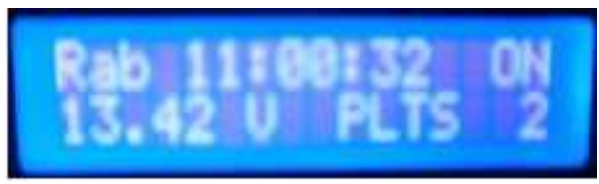

Gambar 4.8 Baterai 2 sebagai suplai fingerprint

Dari gambar 4.8 terlihat tampilan dari LCD saat baterai 2 digunakan sebagai suplai pengoperasian fingerprint berupa angka 2 pada ujung bawah sebelah kanan LCD, tertulis juga besar tegangan dari PLTS saat sedang mengecas baterai 2 pada ujung kiri bawah LCD, serta tampilan dari hari dan jam pada baris atas LCD.

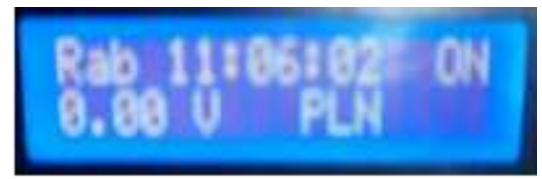

Gambar 4.9 PLN sebagai suplai fingerprint

Dari gambar 4.9 terlihat tampilan dari LCD saat sumber listrik dari PLN digunakan sebagai suplai pengoperasian fingerprint. Ini terjadi saat baterai 1 dan baterai 2 pada tegangan dibawah 12,30 volt serta PLTS tidak dapat menghasilkan tegangan yang cukup untuk pengecasan baterai.

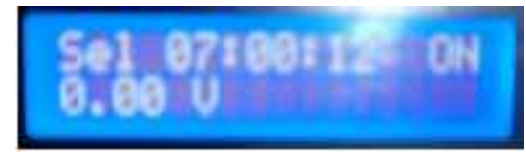

Gambar 4.10 Fingerprint menyala 
Gambar 4.10 memperlihatkan tampilan LCD ketika fingerprint dalam kondisi menyala, hal ini dapat dilihat dengan adanya tulisan ON pada tampilan LCD. Tampilan LCD akan menuliskan kata ON ketika fingerprint menyala dan akan menuliskan kata OFF ketika fingerprint mati.

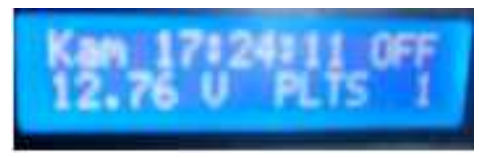

Gambar 4.11 Fingerprint mati

Gambar 4.11 memperlihatkan tampilan LCD ketika fingerprint dalam kondisi mati, hal ini dapat dilihat dengan adanya tulisan OFF pada tampilan LCD. Tampilan LCD akan menuliskan kata ON ketika fingerprint menyala dan akan menuliskan kata OFF ketika fingerprint mati.

Switching otomatis pengoperasian fingerprint akan membuat fingerprint hanya menyala pada hari senin - jum'at pukul 07.00 - 17.00, selain pada waktu tersebut fingerprint akan mati.

\subsubsection{Tampilan Fingerprint}

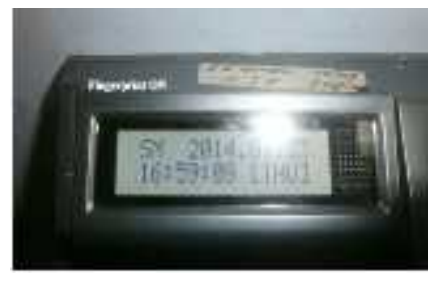

Gambar 4.12 Fingerprint menyala

Gambar 4.12 memperlihatkan tampilan fingerprint ketika menyala. Sesuai dengan pengaturan alat, maka fingerprint akan menyala pada hari senin sampai jum'at pukul 07.00 - 17.00.

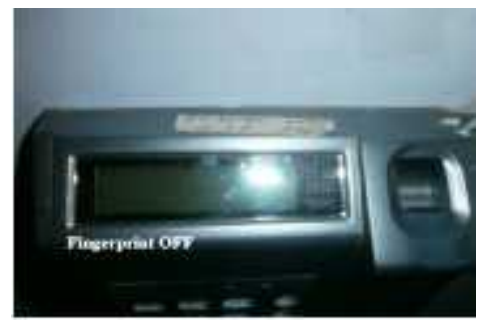

Gambar 4.13 Fingerprint mati
Gambar 4.13 memperlihatkan tampilan fingerprint ketika mati. Kondisi ini akan terjadi selain dari hari senin - jum' at pukul $07.00-17.00$.

\section{KESIMPULAN}

\subsection{Kesimpulan}

Dari serangkaian penelitian, pengujian, dan analisa yang telah dilakukan dapat disimpulkan bahwa:

1. PLTS dapat berfungsi sebagai sumber suplai utama pengoperasian fingerprint, dan PLN sabagai sumber cadangan.

2. Battery charge controller dual sumber suplai beban dapat menyuplai beban dengan dua sumber secara bergantian menggunakan mikrokontroler sebagai pengendalinya.

3. Sistem switching otomatis pengoperasian fingerprint dapat bekerja dengan baik. Fingerprint hanya akan beroperasi pada pukul 07.00 - 17.00 WIB ( sesuai dengan pengaturan dalam bahasa pemrograman mikrokontroler ).

\section{DAFTAR PUSTAKA}

[1] Ardi Winoto, Mikrokontroller AVR ATmega 8/32//16/8535 dan Pemogramannya dengan Bahasa $\mathrm{C}$ pada WinAVR.2008.

[2] Aplikasi RTC1307 Dengan Mikrokontroler Dengan Sdcc. 2013. hal 2-5. $<$ http://Training.umy.ac.id > dipublikasikan 8 April 2013.

[3] I Made Astra, Satwiko Sidopekso, Studi Rancang Bangun Solar Charge Controller dengan Indikator Arus, Tegangan dan Suhu Berbasis Mikrokontroler ATMEGA 8535. Universitas Negeri Jakarta. Jakarta. Spektra: Jurnal Fisika dan Aplikasinya, Vol. XI No.1 Mei 2011.

[4] Liem Ek Bien, Ishak Kasim \& Wahyu Wibowo, 2008. Perancangan Sistem Hibrid Pembangkit Listrik Tenaga Surya dengan Jala - Jala Listrik PLN untuk Rumah Perkotaan. Universitas Trisakti. JETri,Volume 8, Nomor 1, Agustus 2008. 